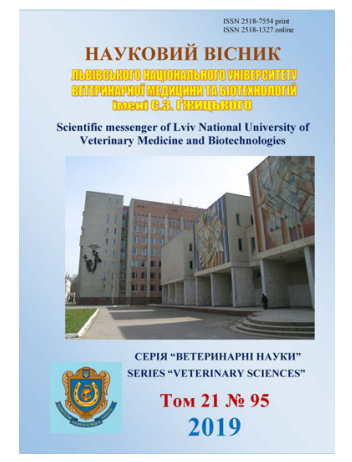

\author{
Науковий вісник Иьвівського національного університету \\ ветеринарної медицини та біотехнологій імені С.3. Гжицького. \\ Серія: Ветеринарні науки \\ Scientific Messenger of Lviv National University \\ of Veterinary Medicine and Biotechnologies. \\ Series: Veterinary sciences
}

\title{
Actual problems of food safety for the population living in the contaminated areas due to the Chernobyl disaster in the context of food security
}

\author{
V.A. Kotelevych \\ Zhytomyr National Agroecological University, Zhytomyr, Ukraine
}

Article info

Received 23.09.2019

Received in revised form 24.10.2019

Accepted 25.10.2019

Zhytomyr National Agroecological University, Korolova Str., 39, Zhytomyr, 10025, Ukraine Tel.: +38-067-456-23-80 E-mail: valya.kotelevich@ukr.net
Kotelevych, V.A. (2019). Actual problems of food safety for the population living in the contaminated areas due to the Chernobyl disaster in the context of food security. Scientific Messenger of Lviv National University of Veterinary Medicine and Biotechnologies. Series: Veterinary sciences, 21(95), 156-160. doi: 10.32718/nvlvet9529

The purpose of the research was to determine the current problems of food safety for the population received from radioactively contaminated as a result of the Chernobyl disaster. The material for the research was the reporting documentation of the Zhytomyr Regional State Laboratory of the State Service for Food Safety and Consumer Protection, the SLVSI of the markets of Zhytomyr and Zhytomyr region; The Rivne Regional State Laboratory of the State Service for Food Safety and Consumer Protection, the State Market for Forestry and Food of the markets of Rivne and Rivne regions; samples of meat and milk, game, wild berries and mushrooms. Radiological examination of the samples was performed on the device USK Gamma-plus No. 0502 BG. Specific activity of mushrooms was determined - on the device RUG-91. In 2017, the experts of the RSRDDPSS found that the maximum activity of milk samples exceeding 137Cs was 197 Bq/l, fresh mushrooms $-706 \mathrm{~Bq} / \mathrm{kg}$ and $877 \mathrm{~Bq} / \mathrm{kg}, \mathrm{dry}-2787 \mathrm{~Bq} / \mathrm{kg}$ and $4193 \mathrm{~Bq} / \mathrm{kg}$. According to the DLVSE of the Zhytomyr region, the maximum activity in dried berries and mushrooms is $4000 \mathrm{~Bq} / \mathrm{kg}$ and $4762 \mathrm{~Bq} / \mathrm{kg}$, respectively. The highest number of exceedances was recorded in Narodichi and Ovruc, slightly less - in Emilchin, Korosten, Luhin and Olevsky. In Ovruch region - 72.7\% of samples showed exceedances, including maximum values of mushroom activity ranged from $8700 \mathrm{~kg}$ to $17293,17.4$ and 34.6 respectively, which exceeds the permissible levels; maximum values of 137Cs activity in milk were 123-272 Bq/l, meat (mainly wild animals) - 2243-51455 Bq/ $\mathrm{kg}$. The level of contamination of game significantly exceeds the regulatory requirements: from Ovruch - 2.3 times, from Lugin - 3.3 times and from Narodichi - 7.6 times. In 2018, $50 \%$ of dry mushroom samples from the Ovruch region exceeded the permitted levels: $2529-5000 \mathrm{~Bq} / \mathrm{kg}$. Accordingly, 5.8\% of Yemil'chynskyi (2544-2923 Bq/kg), 7.2\% of Narodichiv (3971-29022 Bq/kg). Of SLVSI studied, 69 fresh mushroom samples did not meet the regulatory requirements in Novograd-Volynsk 11.6\% (866-1310 Bq/cl), Yemilchino - 8.75\% (526-894 Bq/kg and Lugina 1.4\% (504 Bq) According to the data, in 2018 from 7246 food samples tested, 16 samples exceeded the limit values by the content of 137Cs. $\mathrm{kg}$ and Narodichsky - $1531 \mathrm{~Bq} / \mathrm{kg}$. Fresh mushrooms - specific activity of 5 specimens from Ovruch district was at the level of 509.1-3375 Bq/kg), sample from Narodichsky - $1956 \mathrm{~Bq} / \mathrm{kg}$ and 3 samples in the Zhytnyi market at Zhytomyr - 2328-2345 Bq/kg. Mushrooms are dry - the specific activity of the sample from the Ovruch region was $8329 \mathrm{~Bq} / \mathrm{kg}$ and Olevsky $2814 \mathrm{~Bq} / \mathrm{kg}$, 2 samples from Narodychy - $4330 \mathrm{~Bq} / \mathrm{kg}$ and 4987 Bq/kg. As of September 1, 2019, 3504 samples were examined by the radiological department of the Department of Radiology, 6 of which exceeded the permitted levels. Including the specific activity of the game sample from the Ovruch region was $407 \mathrm{~Bq} / \mathrm{kg} ; 2$ samples of fresh mushrooms and berries from Luginsk district - $809 \mathrm{~Bq} / \mathrm{kg}$ and $825 \mathrm{~Bq} / \mathrm{kg}$; sample of milk from Olevsky district - 107.4 Bq/l and Luginsky $-149.7 \mathrm{~Bq} / \mathrm{l}$.

Key words: cesium-137, strontium-90, food security, specific activity. 


\title{
Актуальні проблеми безпечності харчових продуктів для населення, що проживає на забруднених внаслідок аварії на ЧАЕС територіях, у контекс- ті гарантування продовольчої безпеки
}

\author{
В.А. Котелевич
}

Житомирський національний агроекологічний університет, м. Житомир, Украӥна

\begin{abstract}
Метою досліджень було визначити актуальні проблеми безпечності харчових продуктів для населення одержаних з радіоактивно забруднених внаслідок аварії на ЧАЕС територій. Матеріалом для досліджень була звітна документація Житомирської регіональної державної лабораторії Державної служби з питань безпечності харчових продуктів та захисту споживачів (ЖРДЛДПСС), ДЛВСЕ ринків м. Житомира і Житомирської області; Рівненської регіональної державної лабораторії Державної служби з питань безпечності харчових продуктів та захисту споживачів (РРДДДПСС), ДЛВСЕ ринків м. Рівного та Рівненської області; зразки м'яса і молока, дичини, лісових ягід та грибів. Радіологічні дослідження зразків проводили на приладі УСК Гамма-плюс № 0502 Б-Г. Питому активність грибів визначали - на приладі РУГ-91. У 2017 роиі фахівиями РРДДДПСС встановлено, що максимальна активність зразків молока з перевищенням ${ }^{137}$ Сs складала - 197 Бк/л, грибів свіжих - 706 Бк/кг i 877 Бк/кг, сухих 2787 Бк/кг та 4193 Бк/кг. За данними ДЛВСЕ Житомирської області, максимальна активність в сухих ягодах та грибах відповідно складає 4000 Бк/кг та 4762 Бк/кг. Найбільша кількість перевищень реєструвалась у Народиџькому та Овруцькому, дещо менше Смільчинському, Коростенському, Лугинському і Олевському.В Овруиькому районі - 72,7\% проб показали перевищення, в $m .4$. максимльні значення активності грибів сягали від 8700 до 17293 Бк/кг, щьо відповідно в 17,4 та 34,6 перевищує допустимі рівні; максимальні значення активності ${ }^{137}$ Cs у молочі були на рівні 123 - 272 Бк/л, м'ясі (переважно диких тварин) - 2243-51455 Бк/кг. Рівень забрудненя дичини значно перевищує нормативні вимоги: з Овруча - у 2,3 рази, з Лугин - у 3,3 рази та з Народичів - у 7,6 разів. У 2018 роиі 50\% проб сухих грибів з Овруцького району перевищували допустимі рівні: 2529-5000 Бк/кг. Відповідно 5,8\% з Смільчинського (2544-2923 Бк/кг), 7,2\% з Народичів (3971-29022 Бк/кг). 3 досліджених ДЛВСЕ 69 проб свіжих грибів не відповідали нормативним вимогам у Новоград-Волинську 11,6\% (866-1310 Бк/кл), Смільчино - 8,75\% (526-894 Бк/кг та Лугіни 1,4\% (504 Бк/кг). За данними ЖРДЛДПСС, у 2018 рочі з досліджених 7246 проб харчових продуктів 16 зразків перевищували гранично допустимі рівні за вмістом ${ }^{137}$ Cs. Зокрема, питома активність зразка дичини з Овруцького району була на рівні 464 Бк/кг), Лугинського - 634 Бк/кг і Народичського - 1531 Бк/кг. Гриби свіжі - питома активність 5 зразків з Овручського району була на рівні 509,1-3375 Бк/кг), проба з Народичського - 1956 Бк/кг та 3 зразки на Житньому ринку м. Житомира - 2328-2345 Бк/кг. Гриби сухі - питома активність зразка з Овручського району становила 8329 Бк/кг та Олевського 2814 Бк/кг, 2 зразки з Народичського 4330 Бк/кг і 4987 Бк/кг. Станом на 1.09.2019 року радіологічним відділом ЖРДЛДПСС досліджено 3504 проби, 63 яких перевищували допустимі рівні. В т.ч. питома активність зразка дичини з Овруиького району становила 407 Бк/кг; 2 зразки грибів та ягід свіжих з Лугинського району - 809 Бк/кг та 825 Бк/кг; зразок молока з Олевського району - 107,4 Бк/л та Лугинського - 149,7 Бк/л.
\end{abstract}

Ключові слова: иезій-137, стронцій-90, продовольча безпека, питома активність

\section{Вступ}

Одним з найважливіших чинників для загального добробуту та розвитку країни є продовольча безпека. Як зазначають В.П. Ільчук, Х.I. Штирхун (Ilchuk \& Shtyrkhun, 2019), поняття “продовольча безпека" 3'явилося у 1996 році і затверджено Світовим самітом з продовольства (World Food Summit), як стан, в якому всі люди в будь-який час мають фізичний та економічний доступ до достатньої у кількісному вираженні, безпечної та поживної їжі, яка відповідає їхнім дієтичним потребам та харчовим вподобанням для ведення активного та здорового життя. Глобальний індекс продовольчої безпеки України (Global Food Security Index), який розраховується на основі чотирьох груп показників для 113 країн світу, у 2018 році становив 55,7 бала зі 100, або відповідав 63 місцю (Marteniuk, 2018),

Особливо гостро питання продовольчої безпеки для населення постає на радіоактивно забруднених внаслідок аварії на ЧАЕС територіях Поліського регіону (Romanchuk, 2011; Romanchuk, 2015; Kotelevych \& Skladenko, 2019; Kotelevych, 2019). Як наголошують вчені (Sokolova \& Honta, 2019), нині і в майбутньому цезій-137, як і раніше, залишатиметься основним радіонуклідом, що впливає на стан здоров'я людей, які проживають в цих районах. Період напівроз- паду цього радіонукліда становить 29,7 року. Крім ${ }^{137} \mathrm{Cs}$, небезпеку для здоров'я населення становлять стронцій-90 (період напіврозпаду 28 років), америцій241 (період напіврозпаду 432,2 року) і плутоній-239 (період напіврозпаду 24000 років). Ці радіонукліди потрапляють в організм як у складі харчових продуктів, так і з повітряними потоками у разі виникнення лісових пожеж і горіння трави.

Однією 3 принципових помилок у ході ліквідації аварії на ЧАЕС було прийняття як основного критерію радіаційної безпеки щільності радіоактивного забруднення територій, а не дози опромінення людини. Це призвело до помилкових оцінок, адже просторовий розподіл дози внутрішнього опромінення визначається в значно більшій мірі екологічними факторами, ніж щільністю випадінь ${ }^{137} \mathrm{Cs}$. У віддаленних на 300 км від ЧАЕС населенних пунктах на торф'яних грунтах за рівнів забрудненя менше ніж $15 \mathrm{Ki} /$ км² $^{2}$ доза виявилась вищою, ніж ближче до епіцентру аварії на мінеральних грунтах. Лише на 25-му році після аварії як основу оцінок радіаційної небезпеки прийнято дози внутрішнього опромінення (Romanchuk, 2015), А.О. Соколова, Н.А. Гонта наголошують, що продовольча безпека держави забезпечується за рахунок гарантування продовольчої безпеки в кожному їі регіоні, що обумовлено особливістю природнокліматичних умов, рівнем виробничо-економічного 
розвитку, соціально-демографічною ситуацією тощо (Sokolova \& Honta, 2019).

На думку (Skydan et al., 2019), проблема продовольчої безпеки тісно пов'язана 3 якістю життя населення; задовольнити іiі - означає забезпечити населення безпечними продуктами харчування та створити фінансові можливості. За результатами досліджень цих вчених встановлено, що 87,1\% сільського населення на радіоактивно забруднених територіях Житомирщини споживає молоко власного виробництва, м'ясо власного виробництва - 50\%, 10\% споживає м'ясо диких тварин. Споживання риби із місцевих водойм за рік становить 17,5 кг на людину, яєць - 86, картоплі власного виробництва - 183,3 кг, а також фрукти i ягоди власного виробництва та гриби і ягоди лісові. За наявними в науковій літературі оцінками, доза внутрішнього опромінення людини навіть через 29 років після аварії̈ на ЧАЕС формується від 75 до 90\% за рахунок молока і молочних продуктів місцевого виробництва.

Беручи до уваги вищезазначене, оцінка вмісту радіонуклідів у продуктах харчування населення радіоактивно забруднених внаслідок аваріїнв ЧАЕС територій у контексті гарантування продовольчої безпеки вимагає вирішення шляхом ефективної політики 3 боку держави. Гарантом безпеки харчової продукції в постчорнобильський період в Україні залишається система моніторингових досліджень. А отже, належна увага має приділятися питанням моніторингових досліждень щодо оцінки якості харчових продуктів на цих територіях, інформування населення та розробка заходів і методів, що сприяють зниженню надходження цих радіонуклідів за ланцюгом грунт - рослина - тварина - продукти харчування. Оскільки на даний час основна частина дози внутрішнього опромінення мешканців радіоактивно забруднених територій Поліського регіону формується за рахунок надходження ${ }^{137} \mathrm{Cs} 3$ місцевими продуктами домашнього господарства - молоком та продуктами лісового походження - насамперед сушеними грибами та ягодами, метою наших досліджень було визначити актуальні проблеми безпечності харчових продуктів населення радіоактивно забруднених внаслідок аварії нв ЧАЕС територій у контексті гарантування продовольчої безпеки.

\section{Матеріал і методи досліджень}

Матеріалом наших досліджень була звітна документація Житомирської регіональної державної лабораторії Державної служби з питань безпечності харчових продуктів та захисту споживачів (ЖРДЛДПСС), державних лабораторій ВСЕ господарчих ринків м. Житомира і Житомирської області; Рівненської регіональної державної лабораторії Державної служби з питань безпечності харчових продуктів та захисту споживачів (РРДЛДПСС), державних лабораторій ветсанекспертизи агропродовольчих ринків м. Рівного та Рівненської області; зразки м'яса і молока, дичини, лісових ягід та грибів. Радіологічні дослі- дження зразків проводили на приладі УСК Гама-плюс № 0502 Б-Г. Питому активність грибів визначали на приладі РУГ-91.

Дослідження 3 визначення питомої активності ${ }^{137} \mathrm{Cs}$ у зразках молока, м'яса та кормів з господарств та $з$ сіл “жорсткого” контрою північних районів Рівненської області проводилися в стійловий та пасовищний періоди. Проби для досліджень доставлялися в радіологічний відділ РРДЛДПСС згідно "Графіком відбору проб” радіологом Сарненської МДЛ (міжрайонної державної лабораторії) Держпродспоживслужби. Радіологічний контроль об'єктів ветнагляду в північних районах області включає: радіометричні дослідження молока, м'яса, кормів та ін. 3 господарств та від індивідуальних власників з Сарненського, Дубровицького, Зарічнянського районів. Дослідження включали: органолептичні та радіологічні.

\section{Результати та їх обговорення}

За даними звітної документації, у 2017 році фахівцями Рівненської РДДДПСС проведено 388 досліджень на вміст цезію-137 з господарств та приватного сектору області: кормів - 55 проб; молока - 322 проби. В т. ч. було виявлено 5 зразків молока 3 порушенням допустимих рівнів: мінімальна активність 3 перевищенням ${ }^{137} \mathrm{Cs}$ складала 107 Бк/л, а максимальна 197 Бк/л (допустимий рівень 100 Бк/л). М'яса досліджено 6 проб; грибів - 5 зразків. В т. ч. 4 проби 3 підвищеним вмістом радіонуклідів ${ }^{137} \mathrm{Cs}$ : мінімальна активність з перевищенням в свіжих грибах складає 706 Бк/кг, максимальна в свіжих - 877 Бк/кг (допустимий рівень 500 Бк/кг), а в сухих грибах - 3785 Бк/кг (допустимий рівень 2500 Бк/кг). Середня забрудненість грубих кормів становила - 27 Бк/кг, соковитих 15 Бк/кг; коренеплодів - 3,6 Бк/кг; концкормів 4 Бк/кг; молока - 19 Бк/л. Молоко вище допустимих рівнів виявлено в Зарічнянському і Дубровицькому районах, гриби - в Дубровицькому районі. Проведений радіологічний контроль об'єктів ветнагляду в північних районах області: радіометричні дослідження молока, м'яса, кормів та інших об'єктів ветнагляду 3 господарств та від індивідуальних власників з Сарненського, Дубровицького, Зарічнянского районів радіологом Сарненської МДЛ Держпродспоживслужби у 2017 році показав, що з 354 проб кормів, 46 зразків фруктів та овочів, 369 проб молока, 15 проб грибів та ягід лише 2 проби сухих грибів перевищували ДР (мінімальна активність з перевищенням складає - 2787 Бк/кг, а максимальна - 4193 Бк/кг. Порівняно з минулим роком забрудненість молока, кормів в індивідуальному секторі дещо зменшилась. Державними лабораторіями ВСЕ на ринках Рівненської області у 2017 році проведено 145740 досліджень на вміст цезію-137, в т. ч 66 проб з перевищенням допустимих рівнів (ягоди та гриби), мінімальна активність в свіжих ягодах та грибах 3 перевищенням складає 589 Бк/кг, в сухих - 2566 Бк/кг, максимальна активність в свіжих ягодах та грибах - 4000 Бк/кг, а в сухих -4762 Бк/кг. 
Аналіз звітної документації служби радіологіного контролю в Житомирський області за 2017 рік показав, що найбільша кількість перевищень у зразках продуктів тваринного походження реєструвалась у найбільш забруднених Народицькому та Овруцькому районах, дещо менше - Смільчинському, Коростенському, Лугинському і Олевському. Загалом у цих 6 районах питома вага перевищень допустимого рівня ${ }^{137} \mathrm{Cs}$ у молоці та м'ясі відповідно становила 0,8 $2,6 \%$ та 0,7-2,4\%. Максимальні значення активності ${ }^{137} \mathrm{Cs}$ у молоці були на рівні 123-272 Бк/л ( норма 100 Бк/л), м'ясі - 2243-51455 Бк/кг (норма 200 Бк/кг). Варто зазначити, що переважна більшість випдків перевищення допустимих рівнів вмісту ${ }^{137} \mathrm{Cs}$ була у зразках м'яса диких тварин. Забруднення дарів лісу в потерпілих внаслідок аварії на ЧАЕС районах Житомирської області залишається на досить високому рівні, вони є основним джерелом небезпеки для споживачів. Значна кількість перевищень була виявлена у зразках лісових грибів та ягід. Зокрема, у Овруцькому районі - 72,7\% проб. Максимальні значення активності грибів сягали від 8700 до 17293 Бк/кг, що відповідно в 17,4 та 34,6 перевищує гранично допустимі рівні. Із 16337 відібраних в 2017 році зразків харчових продуктів у 81 населенному пункту Житомирської області перевищення допустимих рівнів спостерігалися у $144(0,9 \%)$ зразках з 38 населенних пунктів. У 2018 році визначено 5 проб свіжих грибів з Овруча, питома активність яких перевищувала нормативні вимоги ДР за вмістом цезію-137 і становила 509,13375 Бк/кг, зразок з Народичів - 1956 Бк/кг та Житнього ринку м. Житомира 3 проби - 2328-2345 при нормі 500 Бк/кг. Відповідно зразки сухих грибів перевищували нормативні вимоги 2500 Бк/кг з Овруча проба - 6329 Бк/кг, з Народичів - 2 проби (4330 Бк/кг i 4987 Бк/кг) та з Олевська 1 проба (2814 Бк/кг). Загалом у Житомирський області з дослідженних державними лабораторіями ВСЕ 69 проб свіжих грбів не відповідали нормативним вимогам у НовоградіВолинському 11,6\%, (866-1310 Бк/кл), Смільчиному - 8,75\% (526-894 Бк/кг та Лугинах - 1,4\% (504 Бк/кг). При дослідженні 28 проб сухих грибів встановлено, що вони є найбільш небезпечними в раціоні населення. Зокрема, 50\% проб з Овруцького району перевишувала нормативні вимоги, питома активність яких становила 2529- 5000 Бк/кг. Відповідно 5,8\% з Смільчинського району (2544-2923 Бк/кг), 7,2\% з Народичів - 3971-29022 Бк/кг. Велику небезпеку для населення потерпілих районів становить дичина, рівень забрудненя якої значно перевищує номативні вимоги. Зокрема, 1 зразок з Овруча перевищував норми у 2,3 разу, 2 зразки з Лугин - у 3,3 раз та з Народичів у 7,6 разу. Питома активність 4 - зразків дичини в Народичах становила 2000-12124 Бк/кг, в Малині 2 проб - 730-920 Бк/кг. Небезпеку становлять і продукти власного виробництва. Зокрема, питома активність зразка м'яса ВРХ в Коростині була на рівні 1500 Бк/кг (при ДР 200 Бк/кг). 348 проб молока, досліджених ДЛВСЕ в Народичах, жодна не відповідала нормативним вимогам (101-172 Бк/л). За данними ЖРД-
ЛДПСС, у 2018 році з досліджених 7246 проб харчових продуктів 16 зразків перевищували гранично допустимі рівні за вмістом ${ }^{137} \mathrm{Cs}$. Зокрема, питома активність зразка дичини з Овруцького району була на рівні 464 Бк/кг (допустимий рівень 200 Бк/кг), Лугинського - 634 Бк/кг i Народичського 1531 Бк/кг. Гриби свіжі - питома активність 5 зразків 3 Овручського району була на рівні 509,1-3375 Бк/кг), проба з Народичського 1956 Бк/кг та 3 зразки на Житньому ринку м. Житомира - 2328-2345 Бк/кг. Гриби сухі - питома активність зразка з Овручського району становила 8329 Бк/кг та Олевського 2814 Бк/кг, два зразки з Народичського - 4330 Бк/кг і 4987 Бк/кг. Станом на 1.09.2019 року радіологічним відділом ЖРДЛДПСС досліджено 3504 проби, 6 з яких перевищували допустимі рівні (ДР-2006). В т.ч. питома активність зразка дичии з Овруцького району становила 407 Бк/кг; два зразки грибів та ягід свіжих 3 Лугинського району - 809 Бк/кг та 825 Бк/кг; зразок молока з Олевського району - 107,4 Бк/л та Лугинського - 149,7 Бк/л. Таким чином, наведені вище данні свідчать про актуальність продовольчої безпеки у потерпілих внаслідок аварії на ЧАЕС районах Поліського регіону.

\section{Висновки}

1. Вміст радіонуклідів у грибах, ягодах, дичині та продуктах власного виробництва у забруднених внаслідок аварії на ЧАЕС регіонах в більшості випадків значно перевищує допустимі рівні, що формує великі дози внутрішнього опромінення і негативно впливає на стан здоров'я населення.

2. Для усунення ризику небезпек споживача харчової продукції необхідно удосконалювати систему контролю сировини, яку використовують для виготовлення продуктів, за показниками безпеки на всіх етапах виробництва “від лану - до столу”.

3. Для забезпечення продовольчої безпеки необхідно посилити радіологічний контроль харчових продуктів та проводити знищення тих, що не відповідають допустимим рівням; застосовувати додаткові методи технологічної переро-бки харчової сировини; обмежувати вживання дарів лісу; застосувати різні методи зниження індивідуальних доз (у т. ч. контроль за використанням калійних добрив і фероціанідних добавок у кормах тваринам та організація раціонального використання природних ресурсів); інформувати населення щодо небезпечності харчових продуктів власного виробництва і дарів лісу та забезпечувати його безпечними і доступними продуктами харчування.

4. Актуальність продовольчої безпеки у потерпілих районах Поліського регіону вимагає прийняття рішень на державному рівні, адже продовольча безпека держави забезпечується за рахунок гарантування продовольчої безпеки в кожному ії регіоні. 


\section{References}

Ilchuk, V.P. \& Shtyrkhun, Kh.I. (2019). Rynok orhanichnoi produktsii u zabezpechenni prodovolchoi bezpeky Ukrainy. Orhanichne vyrobnytstvo i prodovolcha bezpeka: [materialy dop. VII Mizhnar. nauk.-prakt. konf.] Zhytomyr: ZhNAEU (in Ukrainian).

Kotelevych, V.A. (2019). Actual problems of quality and safety of food products in the context of providing food security in the Zhytomyr region. Scientific Messenger of Lviv National University of Veterinary Medicine and Biotechnologies. Series: Veterinary sciences, 21(93), 155-159. doi: 10.32718/nvlvet9327.

Kotelevych, V.A., \& Skladenko, T.V. (2019). Yakist i bezpechnist kharchovykh produktiv V postchornobylskyi period v Zhytomyrskomu rehioni. Naukovi zdobutky u vyrishenni aktualnykh problem vyrobnytstva ta pererobky syrovyny, standartyzatsii i bezpeky prodovolstva: zb. prats za pidsumkamy VIII Mizhnar. nauk.-prakt. konf. vchenykh, asp. i studentiv. Kyiv, 96-98 (in Ukrainian).

Marteniuk, H.M. (2018). Monitorynh radiatsiinoho zabrudnennia kharchovykh produktiv v Zhytomyrskyi oblasti. Chornobylska katastrofa. Aktualni problemy, napriamky ta shliakhy yikh vyrishennia : dop. Mizhnar. nauk.-prakt. konf. (26-27 kvitnia 2018 r.). Zhytomyr: ZhNAEU, 324-329 (in Ukrainian).
Ofitsiinyi sait Hlobalnoho indeksu prodovolchoi bezpeky (Global Food Security Index) [Elektronnyi resurs]. Rezhym dostupu: https: //foodsecurityindex.eiu.com.

Romanchuk, L.D. (2011). Vplyv hrybiv na formuvannia vnutrishnoho oprominennia naselennia Pivnichnoi chastyny Ukrainy. Visn. ahrar. Nauky, 3, 44-47. http://ir.znau.edu.ua/bitstream/123456789/3199/1/Vis nyk_AN_2011_3_44-46.pdf (in Ukrainian).

Romanchuk, L.D. (2015). Radiolohichna otsinka formuvannia dozovoho navantazhennia u meshkantsiv silskykh terytorii Polissia Ukrainy: monohrafiia. Zhytomyr: Polissia (in Ukrainian).

Skydan, O.V., Romanchuk, L.D.. \& Dovzhenko, V.A. (2019). Otsinka rivnia kharchuvannia silskoho naselennia radioaktyvno zabrudnenykh terytorii $\mathrm{u}$ konteksti harantuvannia prodovolchoi bezpeky. Naukovi horyzonty, 76(3), 3-9. http://journal.znau.edu.ua/horizons/article/view/176 (in Ukrainian).

Sokolova, A.O., \& Honta, N.A. (2019). Monitorynh prodovolchoho zabezpechennia naselennia: rehionalnyi aspekt. Orhanichne vyrobnytstvo i prodovolcha bezpeka: [materialy dop. VII Mizhnar. nauk.-prakt. konf.]. Zhytomyr: ZhNAEU, 106 (in Ukrainian). 